\title{
Respect and Relational Contracts
}

\author{
Tor Eriksson \\ Aarhus School of Business and Social Sciences and CCP, Aarhus University \\ Marie Claire Villeval \\ GATE-CNRS, University of Lyon
}

\begin{abstract}
Assuming that people care not only about what others do but also on what others think, we study respect in a labor market context where the length of the employment relationship is endogenous. In our three-stage gift-exchange experiment, the employer can express respect by giving the employee costly symbolic rewards after observing his level of effort. We study whether symbolic rewards are used by the employers mainly to praise employees or as a coordination device to build relational contracts by manipulating the balance between labor demand and supply in the market. We find that a high proportion of long-term relationships have been initiated by the assignment of symbolic rewards. However, the assignment of symbolic rewards decreases when it becomes clear that the relationship is durable, suggesting that employers mainly use symbolic rewards as a coordination device to initiate relational contracts. Compared to the balanced market condition, assigning symbolic rewards in initial relationships is less likely when there is excess demand in the market and more likely when there is excess supply, i.e. when the relationship is more valuable. Receiving symbolic rewards increases the employees' likelihood of accepting to continue the relationship with the same employer. It also motivates them to increase their effort further but only when the market is balanced. Overall, the ability to assign symbolic rewards does not give rise to higher profits because it is associated with lower rents offered to the employees on average, leading to lower effort levels.
\end{abstract}

Keywords: Respect, Symbolic rewards, Coordination, Signaling, Labor market, Experiment

JEL Codes: C91, J32, J64, M52

Contact : Tor Eriksson, Department of Economics, Aarhus University: Frichshuset, Hermodsvej 22, 8230 Åbyhøj, Denmark. E-mail: tor@asb.dk. Marie Claire Villeval, University of Lyon, F-69007, CNRS - GATE, 93, Chemin de Mouilles, F-69130, Ecully, France. E-mail: villeval@ gate.cnrs.fr.

Acknowledgements: The authors are grateful to participants at a CCP Workshop on Personnel Economics, the $1^{\text {st }}$ joint SEBA-GATE workshop at BNU (Beijing), the EALE-SOLE Conference (London) and the Econometric Society World Congress (Shanghai) for comments on earlier versions. We are also grateful to three anonymous referees for their valuable comments and suggestions. We thank S. Ferriol for skillful programming and J. Rosaz and L. Butera for research assistance in the laboratory. Financial support from the EMIR program of the French National Agency for Research (ANR BLAN07-3_185547) is gratefully acknowledged. 


\section{INTRODUCTION}

Many leadership books provide techniques on how to improve employee engagement (see for example the "carrot principle" of Gostick and Elton, 2004) and they deliver ample anecdotal evidence indicating that employees' productivity may be enhanced by the expression of employers' respect. For example, on the carrots.com website A. Gostick mentions a 2010 McKinsey Quarterly survey indicating that non-monetary motivators are seen as at least as effective than the highest-rated financial incentives. Some websites offer the possibility to send e-cards to colleagues or employees with personalized messages to thank them for smart ideas, extra effort or team success. ${ }^{1}$ It is even possible to attach dollar values to these e-cards. Recognition training seminars have also flourished in companies. These examples suggest that companies become more and more interested in the expression of recognition especially in times where budgets for cash incentives are cut.

It has become increasingly clear that people are motivated by both monetary and nonmonetary incentives, but their interrelationship has become the subject of economic analysis only recently (see Rebitzer and Taylor, 2011; Charness and Kuhn, 2011; Gneezy and Rustichini, 2000). While there is much research on fairness and reciprocity (see e.g., Charness, 2004; Fehr et al., 1993, 1997, 2007; Fehr and Schmidt, 1999), economic work on non-monetary rewards used by the principals to express respect is scarce. ${ }^{2}$ Therefore, we have a rather imprecise economic knowledge on how employers value their employees, how

\footnotetext{
${ }^{1}$ See for example http://thanks.com. We thank an anonymous reviewer for pointing out these references.

2 Exceptions are Falk and Kosfeld (2006) who study the principal's choice of autonomy provided to employees and Dickinson and Villeval (2008) who analyze the choice of monitoring intensity. While both examine ex ante actions (before effort is provided), we are chiefly interested here in the expression of respect by the principal to the agent after effort is provided.
} 
they express it, how they combine it with monetary incentives and how this in turn affects their employees.

A few papers, e.g., Ariely et al. (2009), Ball et al. (2001), Charness et al. (2010), and Kosfeld and Neckermann (2011), examine non-monetary awards as reward schemes. Note that awards are typically made visible to all employees and are in fact used to create positive rivalry among them. Instead, respect can be expressed in such a way that it is only visible to the employee who receives it, as is the case in our study. Here, we define respect as the expression of recognition by an employer to an employee after observing his performance.

The potential importance of paying respect may derive from the fact that people are not only motivated by what others do to them (other-regarding preferences), but also by what others think about them (self-regarding motives); see Ellingsen and Johannesson (2007a and b). ${ }^{3}$ Agents derive utility from thinking of themselves as good, skilled, and valuable (Benabou and Tirole, 2002, 2006), and consequently have a desire for praise and social esteem; Ellingsen and Johannesson (2007a). This could contribute to explain why people enjoy working in firms where managers praise employees (Lazear and Shaw, 2007). ${ }^{4,5}$

\footnotetext{
${ }^{3}$ Ellingsen and Johannesson (2007b) show for example that anticipated verbal feedback from recipients affects the decisions of dividers in a splitting game although the relationship is anonymous and one-shot. Similarly, Xiao and Houser (2007) find that the willingness to avoid negative emotions expression through written messages from the receivers promotes fair exchange in a one-shot dictator game. Even more, Dana et al. (2006) show that many more subjects prefer exiting rather than playing a dictator game when the recipients are informed about the choice faced by the dictator than when uninformed on this option. For a general discussion of how employers show their appreciation of their employees' efforts, see Camerer and Malmendier (2007). ${ }^{4}$ As emphasized by Kandel and Lazear (1992) and subsequent papers on peer pressure (Carpenter and Seki, 2010), employees also value the regard of their co-workers. But this dimension is out of the scope of this study. 5 Social psychologists like Rhoades and Eisenberger (2002) have shown the importance of organizational support on employees; Webster et al. (2003) and Gaines et al. (2005) show the value of praise after a successful performance. Having unsupportive bosses also contributes to predict quits (Cottini et al., 2009).
} 
From the employers' point of view, respect can be used to praise employees' past effort but they can also use it more strategically as a substitute to monetary incentives and as a coordination device to signal their willingness to build a relational contract with a particular employee. If expressing respect is only motivated by the recognition of past effort, it should be expressed continuously over time, even in the final period of interaction. If respect is used as a coordination device, we expect that its use depends on the potential value of the relationship in terms of expected profits to be earned by the employer. Therefore, for a given level of effort, imbalances in the labor market, due either to excess supply or to excess demand of labor, is likely to influence its usage. This paper addresses three sets of questions. First, do employers express respect and if so, is it complementary or substitute to the generosity of contract offers? Second, is respect mainly used to praise employees for past effort or as a coordination device to continue the employment relationship? Third, do employees value respect and does respect increase the probability of accepting an offer from the same firm and further effort?

Testing the role of respect would be very difficult by means of survey or registry data. We have therefore designed a laboratory experiment based on a gift-exchange game. The structure of the baseline treatment is inspired by Brown, Falk and Fehr (2004). The first stage is a trading phase in which employers submit public or private wage offers on the market. In the second stage, the employees who have accepted an offer decide on their level of effort. In the respect treatment, we add a third stage in which the employer can assign symbolic rewards to her employee to express respect. Expressing respect does not affect the employee's payoff but is costly to the employer. Indeed, this cost shows that the employer is a worthy audience, which can increase the value of respect in the eyes of the employee, as 
emphasized by Ellingsen and Johannesson (2007a). Since the game is repeated and players are assigned a permanent identification number, we can observe the renewal of contracts and the influence of respect on this process. If they care about respect, the employees can reward it by continuing the relation and by the choice of effort level in the subsequent period.

We compare three market conditions: one in which there are the same number of employers and employees on the market, one in which there are 8 firms and 12 employees ("excess supply"), and one in which there are 12 firms and 8 employees ("excess demand"). This manipulation allows us to measure whether the expression of respect is affected by the market conditions. If employers express less respect in the excess demand condition and more in the excess supply condition, conditional on the same level of effort, this would suggest that respect is not purely driven by the willingness to praise employees.

Our results show that when the market is balanced $23.31 \%$ of employers express respect by assigning symbolic rewards to their employee. A high proportion of long-term relationships have been initiated by the assignment of symbolic rewards, and assigning symbolic rewards to an employee increases the likelihood of offering him to continue the relationship. This is not true, however, in the excess demand condition when one controls for rents and for the level of effort, probably because the expected profits of continuing the relationship are lower. In this condition, firms are less likely to express respect for a given level of effort, except when they were not able to conclude a contract in the previous period. This supports the notion that employers mostly use respect strategically as a coordination device to initiate contracts. Indeed, the proportion of firms using symbolic rewards is $20.83 \%$ in this condition 
while it reaches $28.80 \%$ when there is excess supply. We also observe that the assignment of symbolic rewards decreases in all conditions when it becomes clear that the relationship is durable, suggesting that employers use symbolic rewards mainly as a coordination device to initiate relational contracts.

On the employees' side, controlling for the generosity of the contract, receiving symbolic rewards increases the likelihood of accepting to remain with the same employer. This is true for all market conditions. In addition, when the market is balanced, it motivates the employees to increase their effort even further, suggesting that employees value being paid respect, and not only money, especially when the bargaining power is balanced. Overall, however, the opportunity to express respect does not enable the firms to increase their profits or the duration of the employment relationships compared to the baseline treatment. Indeed, in the respect treatment employers offer on average lower rents to their employees than in the baseline treatment, which triggers less reciprocity and lowers profitability. When the market is balanced, employers try to substitute respect to monetary rewards and this exerts a depressing effect on wages in general. In addition, when the market is not balanced, the unequal bargaining power limits the value of respect in the employees' eyes and creates an environment that is detrimental to employees' reciprocity.

The remainder of this paper unfolds as follows. Section 2 sets out the design and procedures of the experiment and gives the theoretical predictions. The presentation of our findings is in Section 3. The Section 4 discusses our results and concludes. 


\section{THE EXPERIMENT}

\subsection{Experimental design}

Our experiment is based on a $2 \times 3$ design, that is, it consists of two treatments, the baseline treatment and the respect treatment, each being played under three different market conditions: a balanced labor market, excess supply or excess demand in the labor market.

Our baseline treatment consists of a two-stage gift-exchange game that is played during twelve trading periods. It is close to the design used by Brown, Falk and Fehr (2004) in their incomplete contract condition with a possibility to build long-term relationships. In our balanced labor market condition, in the first stage of each trading period ten firms and ten employees can contract on the labor market during three minutes. ${ }^{6}$ The duration of this trading phase can be shortened if the maximum number of contracts were concluded before the three minutes have elapsed. An identification number is assigned to each firm and each agent that is kept constant until the end of the game. This allows traders to build continuing relationships. $^{7}$ Only firms can submit contracts on the labor market. A contract offer consists of a wage, $w$, and a non-binding desired level of effort, $\hat{e}$, with $w \in(0,1, \ldots, 100)$ and $\hat{e} \in(1,2, \ldots, 10)$. A contract offer can be either public or private. Public offers are made visible to all employees and firms. Private offers are addressed to a specific employee and

\footnotetext{
${ }^{6}$ A major difference with the design of Brown, Falk and Fehr (2004) (henceforth: BFF) is that instructions are contextualized. We use notions such as employer, employee, wage, quality of work. This choice is justified by the nature of our treatment manipulation (see details below). Other differences with our design include the use of separate instructions for employers and employees in BFF, 15 trading periods instead of 12, ten workers and seven firms instead of ten workers and ten firms in our balanced market condition.

${ }^{7}$ A treatment in which identification numbers are randomized after each period would have allowed us to isolate the employers' willingness to send non-strategic signs of approval. However, it would not have highlighted the role of symbolic rewards in building relational contracts.
} 
cannot be observed by other firms or employees. ${ }^{8}$ Irrespective of whether the offer is public or private, the identification numbers of the firms that submit offers are always made visible. A firm can submit as many public and private offers as it desires but it cannot contract with more than one employee and employees can accept at most one contract. The identification numbers of the employees who have not yet accepted an offer are always visible to the firms. As soon as an employee accepts an offer, his identification number disappears from the pool of available employees. All the offers submitted by the employing firm disappear from the market and can therefore not be accepted anymore. The employees can observe all public offers submitted on the market and the private offers that are addressed specifically to them.

As soon as an employee has accepted the offer of a firm, in the second stage he chooses his actual level of effort $e$ with $e \in(1,2, \ldots, 10)$. It is common information that $e$ can differ from the firm's desired level of effort. The effort cost function is convex and the cost schedule for the employees (the same as in BFF, 2004) is displayed in Table 1.

Table 1. The cost of effort

\begin{tabular}{lllllllllll}
\hline Effort & 1 & 2 & 3 & 4 & 5 & 6 & 7 & 8 & 9 & 10 \\
\hline Cost & 0 & 1 & 2 & 4 & 6 & 8 & 10 & 12 & 15 & 18 \\
\hline
\end{tabular}

At the end of this stage, only the employing firm is informed on the actual effort level of its employee. Trading partners are informed on both the firm's and the employee's payoffs. The payoff of the firm is determined as follows:

$\pi^{\mathrm{F}}=10 e-w$ if a contract has been accepted, and 0 otherwise

The payoff of the employee is defined as follows:

${ }^{8}$ On the design of games with public vs. private contracts with an identification of the traders, see also Kirchsteiger et al. (2001). 
$\pi^{\mathrm{E}}=w-c(e)$ if a contract has been accepted, and 5 otherwise

The amount of 5 can be interpreted as an unemployment benefit.

At the end of a period, all contracts are terminated. At the beginning of the next trading phase, like in BFF (2004), no employee has a job and no firm has an employee. Therefore, to continue a relationship a firm has to make a private offer to the same employee as in the previous period and the employee has to choose this offer among the available offers.

The respect treatment is similar to the baseline treatment, except that a third stage is added after the firm observes its employee's actual effort level. In this stage, the firm can send between 0 and 5 symbolic rewards to its employee to express respect. ${ }^{9}$ The symbolic rewards consist of raised thumbs that usually represent approval or praise of somebody's action. ${ }^{10}$ Receiving thumbs does not modify the employee's payoff function that remains the same as in (2). In contrast, each thumb assigned costs one point to the firm. Indeed, paying respect is more than simply expressing praise: whereas the later may not cost anything (and therefore may be hypocritical), the former requires some effort on the part of the person who pays respect. The payoff of the firm in the respect treatment becomes:

$\pi_{\mathrm{R}}^{\mathrm{F}}=10 e-w-s$, if a contract has been accepted, and 0 otherwise

with $s$ denoting the cost of symbolic rewards assigned to the employee.

\footnotetext{
9 In the instructions, we use the term "approval" instead of respect because it is more general and neutral.

${ }^{10}$ In gladiatorial combats in the ancient Rome, a thumb up was considered a signal of approval for a gladiator's life to be spared, although the interpretation is now contested. In medieval times, it has been used to seal transactions. This gesture is today considered as a sign of approval of good behavior in most cultures in Europe, North America or China. Morris, Collett, Marsh and O'Shaughnessy (1979) mention the following answers: «All right, A.O.K., bang on, champion (France), everything's fine, everything's fixed, excellent, fixe (Portugal), good luck, great stuff, I agree, I made it, it's a winner, kalo (Greece), O.K., ready to go, really good, Spitze (Austria), spot on, success, tops, va bene (Italy), very good, victory you've done well. »
} 
Employees know the cost of the thumbs to the firm. In contrast, the number of thumbs bought by a firm is not common information in the market. In all treatments, there is a history box displayed on the participant's screen, showing for each period, whether a contract has been concluded, the identification number of the co-contractor, whether it is private or public, the wage, the demanded level of effort, the actual level of effort, and the number of thumbs given to the employee.

The use of symbolic rewards may express praise of the employee's effort, but it may also be used strategically as a coordination device to prolong a profitable relationship. To capture this dimension, we vary the proportion of firms and employees on the market. In the excess demand condition, 12 firms compete to hire 8 employees. In the excess supply condition, 12 employees compete to contract with 8 firms. Each treatment has been played under the three conditions. If symbolic rewards are used to signal a willingness to continue the employment relationship, for a given level of effort, they should be less frequent when the expected profits from continuing the relationship are lower (i.e., in the excess demand condition).

\subsection{Procedures}

The experiment has been run at the Groupe d'Analyse et de Théorie Economique (GATECNRS), Lyon, France. 180 undergraduate students from the local engineering and business schools participated in this experiment, after receiving an invitation by the ORSEE software (Greiner, 2004). For each of the three conditions (balanced market, excess demand and excess supply), we have conducted three sessions with 20 participants each: in two sessions we implemented the respect treatment (with a possible assignment of thumbs) and in one 
session we implemented the baseline treatment (with no possibility to assign thumbs). Thus, there were in total nine sessions. Nobody participated in more than one session.

The experiment was computerized using the REGATE software (Zeiliger, 2000). Upon arrival, the participants drew a computer tag from a bag and were randomly assigned to a computer terminal. After the instructions were read aloud by the experimentalist, the participants answered an understanding questionnaire (see Appendix). All questions were answered in private. Then the participants played three practice periods with only the trading phase of the game in order to become familiar on how to trade on the market, but without revealing their intentions regarding the choice of effort or the use of symbolic rewards. During these periods, the participants received a provisional identification number. The practice periods were not paid for.

A session lasted on average approximately 90 minutes including the payment of participants. On average the participants earned $€ 14.85$, including a show-up fee of $€ 5$.

\subsection{Predictions}

The equilibrium of the finitely repeated game in the baseline treatment is straightforward. In the second stage of the game, since contracts are incomplete any employee should choose the minimum level of effort that minimizes his cost, i.e. $e^{*}=1$. Therefore, any firm should offer the minimum feasible wage level, $w^{*}=5$. Indeed, since the unemployment benefit amounts to 5, an employee should accept any contract offering at least $w=5$. Firms should be indifferent between posting public or private offers since they should not care about the duration of the contract. These predictions hold for each period and therefore, there is no reason to expect long-term relationships to emerge. 
These predictions are not modified in the respect treatment. Indeed, symbolic rewards should not increase effort since they do not affect employees' earnings. Consequently, firms should never buy symbolic rewards. The share of private contracts, the average duration of contractual relationships, the average wage and effort level should be similar across treatments. When there is excess supply, the predictions are the same as when the market is balanced. When there is excess demand, the competition between firms may motivate firms to offer a higher wage than in the other conditions for increasing their chance to employ a worker. However, in such a situation, the employees still choose the minimum level of effort, $e^{*}=1$, and therefore the firms cannot offer a wage higher than $w=10$ because otherwise they would make a loss. As a result, $w^{*}=10$ is the equilibrium wage in this condition. This indicates that the surplus is captured by the employees, whereas in the other conditions it is captured by the firms. Since effort should be the same as in the other conditions, firms remain indifferent between making private or public offers. Nor is there any reason for more long-term relationships to arise in this condition.

However, we know from the literature on gift-exchange games that the average behavior usually deviates from the standard prediction. Based on the inequity aversion model of Fehr and Schmidt (1999), BFF (2004) show that in the game corresponding to our baseline treatment, if there are sufficiently many fair subjects, there is an equilibrium where all the employees choose a higher than minimum level of effort in all periods except the last one and where only the truly fair subjects choose a non-minimum effort in the last period. Since fair workers reciprocate to the offer of positive rents, the firms offer profitable rents up to the last period and therefore, the prospect of receiving a rent even in the last period disciplines the selfish workers who mimic the truly fair subjects up to the penultimate period. This 
mechanism is facilitated by the possibility of making private offers. In the presence of a sufficiently high proportion of socially oriented subjects, we should observe $e>e^{*}, w>w^{*}$, a positive share of private offers and an average duration of employment relationships significantly higher than 1 . These predictions hold for both treatments and all conditions.

These behavioral predictions assume that people care about what others do. Interested in what happens when people also care about what others think, we assume that people dislike looking selfish and take pride in being thought of as a valuable person. Following Ellingsen and Johannesson (2007), our intuition is that the search for esteem leads to the choice of non-minimum effort levels by a fraction of the employees when principals can express their praise and if their intentions are perceived as being good. Unlike in reciprocity-based models, these employees may exert a non-minimum effort (1) even when they receive a low wage. Long-term relationships are more likely if employees receive praise for their effort.

If firms believe that a sufficient share of employees have a concern for social esteem, they may express respect when the latter choose non-minimum effort levels. Our intuition is that conditional on the same rent offered, the average level of effort, the share of private contract offers and the average duration of the employment relationship should be higher in the respect treatment than in the baseline. However, selfish firms can also use symbolic rewards strategically as a partial substitute for generous rents, up to the penultimate period, if $i$ ) the cost of thumbs is more than compensated for by the additional surplus created by the 
employee's effort and if ii) thumbs increase the willingness of a reciprocal employee to stay in the same firm. ${ }^{11}$

The various market conditions help in identifying the motivation of paying respect. If we observe that, conditional on the same effort level, firms express more respect when there is excess supply of labor and less respect when there is excess demand than in the balanced market condition, this indicates that employers adjust their expression of respect to the expected profits from continuing the relationship. In contrast, if symbols are only used to express respect for past effort, their use should not adjust to the market condition.

\section{RESULTS}

Our analysis of the results focuses on the expression of respect by firms and its consequences on employees' effort and willingness to continue the relationship. Before analyzing the determinants of firms' and employees' behavior and before studying the profitability of the expression of respect we first present some summary statistics.

\subsection{The use of symbolic rewards}

The summary statistics displayed in Table 2 show that the percentage of private offers, wages, and rents offered by the employers to their employee (defined as the difference between the wage offered and the cost of the suggested level of effort), the actual effort exerted by the employees, and the average duration of relationships are higher than expected from standard predictions in all conditions and treatments.

\footnotetext{
11 One additional unit of effort increases the firm's payoff by 10 points while each thumb costs 1 point. Thus, if there is more than $10 \%$ chance that the employee they want to maintain cares about symbols (i.e. accepts an offer from the same firm and increases his effort by at least one unit), they should optimally offer thumbs.
} 
Table 2. Summary statistics

\begin{tabular}{|c|c|c|c|c|c|c|}
\hline \multirow{2}{*}{$\begin{array}{l}\text { Market } \\
\text { condition } \\
\text { treatment }\end{array}$} & \multicolumn{2}{|c|}{ Balanced market } & \multicolumn{2}{|c|}{ Excess demand } & \multicolumn{2}{|c|}{ Excess supply } \\
\hline & Baseline & Respect & Baseline & Respect & Baseline & Respect \\
\hline private & 64.29 & $56.78^{\mathrm{ns}}$ & 41.38 & $57.29^{\mathrm{ns}}$ & 81.25 & $60.21 *$ \\
\hline contracts & (48.13) & (49.64) & (49.54) & (49.59) & (39.24) & (49.08) \\
\hline \multirow[t]{2}{*}{ Wage } & 47.61 & $38.34 * *$ & 75.38 & $53.91 * *$ & 39.68 & $34.04^{\mathrm{ns}}$ \\
\hline & (13.18) & (14.91) & $(7.21)$ & (17.24) & (20.45) & (20.05) \\
\hline Desired & 8.49 & $8.02^{\mathrm{ns}}$ & 9.47 & $8.52 * *$ & 7.17 & $7.37^{\mathrm{ns}}$ \\
\hline effort & (1.96) & (2.23) & $(1.26)$ & (2.14) & (2.92) & (2.73) \\
\hline \multirow[t]{2}{*}{ Rent } & 33.49 & $25.37 * * *$ & 58.79 & $39.65 * * *$ & 28.36 & $22.37^{\mathrm{ns}}$ \\
\hline & $(10.70)$ & (11.74) & $(6.60)$ & $(15.16)$ & (15.34) & (16.16) \\
\hline \multirow[t]{2}{*}{ Actual effort } & 6.24 & $5.43^{\mathrm{ns}}$ & 7.56 & $5.69 * * *$ & 6.08 & $4.89^{\mathrm{ns}}$ \\
\hline & (3.68) & (3.16) & (3.05) & (3.66) & (3.55) & (3.63) \\
\hline \multirow{4}{*}{$\begin{array}{l}\text { Profit all } \\
\text { situations } \\
\text { Profit }\end{array}$} & 13.82 & $15.26^{\mathrm{ns}}$ & 0.15 & $1.64^{\mathrm{ns}}$ & 21.16 & $14.10^{\mathrm{ns}}$ \\
\hline & (29.43) & (21.16) & (23.30) & $(23.51)$ & (19.42) & $(26.82)$ \\
\hline & 14.80 & $15.52^{\mathrm{ns}}$ & 0.25 & $2.47^{\mathrm{ns}}$ & 21.16 & $14.18^{\text {ns }}$ \\
\hline & (30.23) & (21.24) & (30.05) & (28.79) & (19.42) & (26.87) \\
\hline \multirow{2}{*}{$\begin{array}{l}\text { Employee's } \\
\text { payoffs }\end{array}$} & 37.85 & $30.67 * * *$ & 63.10 & $45.35 * * *$ & 30.36 & $27.07^{\text {ns }}$ \\
\hline & (9.96) & $(10.61)$ & (8.42) & (14.09) & (14.34) & (16.24) \\
\hline \multirow{2}{*}{$\begin{array}{l}\text { Sum } \\
\text { payoffs }\end{array}$} & 51.67 & $46.19^{\text {ns }}$ & 63.35 & $47.82 * * *$ & 51.52 & $41.25^{\mathrm{ns}}$ \\
\hline & (29.32) & (25.01) & (24.41) & (28.95) & (28.25) & $(28.65)$ \\
\hline \multirow{4}{*}{$\begin{array}{l}\% \text { contracts } \\
\text { with thumbs } \\
\mathrm{Nb} \text { thumbs }\end{array}$} & - & 23.31 & - & 20.83 & - & 28.80 \\
\hline & & (42.37) & & (40.72) & & $(45.40)$ \\
\hline & - & 0.46 & - & 0.50 & - & 0.69 \\
\hline & & (0.99) & & $(1.17)$ & & (1.32) \\
\hline \multirow{4}{*}{$\begin{array}{l}\mathrm{Nb} \text { thumbs } \\
\text { if thumbs }>0 \\
\text { Average } \\
\text { total length }\end{array}$} & - & 1.98 & - & 2.40 & - & 2.38 \\
\hline & & (1.11) & & (1.43) & & $(1.41)$ \\
\hline & 1.84 & $1.56^{\mathrm{ns}}$ & 1.30 & $1.40^{\mathrm{ns}}$ & 1.98 & $1.80^{\mathrm{ns}}$ \\
\hline & $(2.25)$ & $(1.71)$ & $(0.72)$ & (1.48) & $(2.52)$ & $(1.92)$ \\
\hline Nb obs. & 120 & 240 & 144 & 288 & 96 & 192 \\
\hline $\mathrm{Nb}$ contracts & 112 & 236 & 87 & 192 & 96 & 191 \\
\hline$\%$ contracts & 93.52 & 98.33 & 60.42 & 66.67 & 100 & 99.48 \\
\hline
\end{tabular}

Note: Standard deviations are in parentheses. Only accepted contracts are considered (except in "profit all situations"). This table also shows for each variable and each market condition the degree of significance of comparisons between the baseline treatment and the respect treatment, with $*, * *$, and $* * *$ indicating statistical significance at the $0.10,0.05$, and 0.01 level, respectively, and with ns for non-significance. These indicators are based on Mann-Whitney tests, with each individual as a unit of observation, and they should therefore be taken with caution. Indeed, in a strict sense, each session gives only one independent observation, since there is interaction between individuals over the course of periods. Since we have only a few sessions in each condition and treatment, we have collapsed the choices of each participant to one number. This approach ignores the interactions between the participants but these tests are nevertheless informative.

Overall, we find that $23.31 \%$ of the firms express respect by giving symbolic rewards to their employee when they have the opportunity to do it and when the market is balanced. These firms give on average 1.98 thumbs. These numbers vary with the employees' level of effort and the balance between supply and demand in the market. 
As for the structure of the labor market, the use of symbolic rewards is lowest (highest) when there is excess demand (supply). Indeed, $20.83 \%$ of firms use them in the excess demand condition and $28.80 \%$ in the excess supply condition. The average number of thumbs given is higher when there is competition than when the market is balanced, with 2.40 thumbs assigned in the excess demand condition and 2.38 in the excess supply condition. Figure 1 displays the evolution of the percentage of firms awarding thumbs over time and by market condition. It shows a strong end game effect except in the excess demand condition. We find that in the last period, the percentage of firms still offering thumbs is $7.84 \%$, which cannot be motivated by strategic considerations.

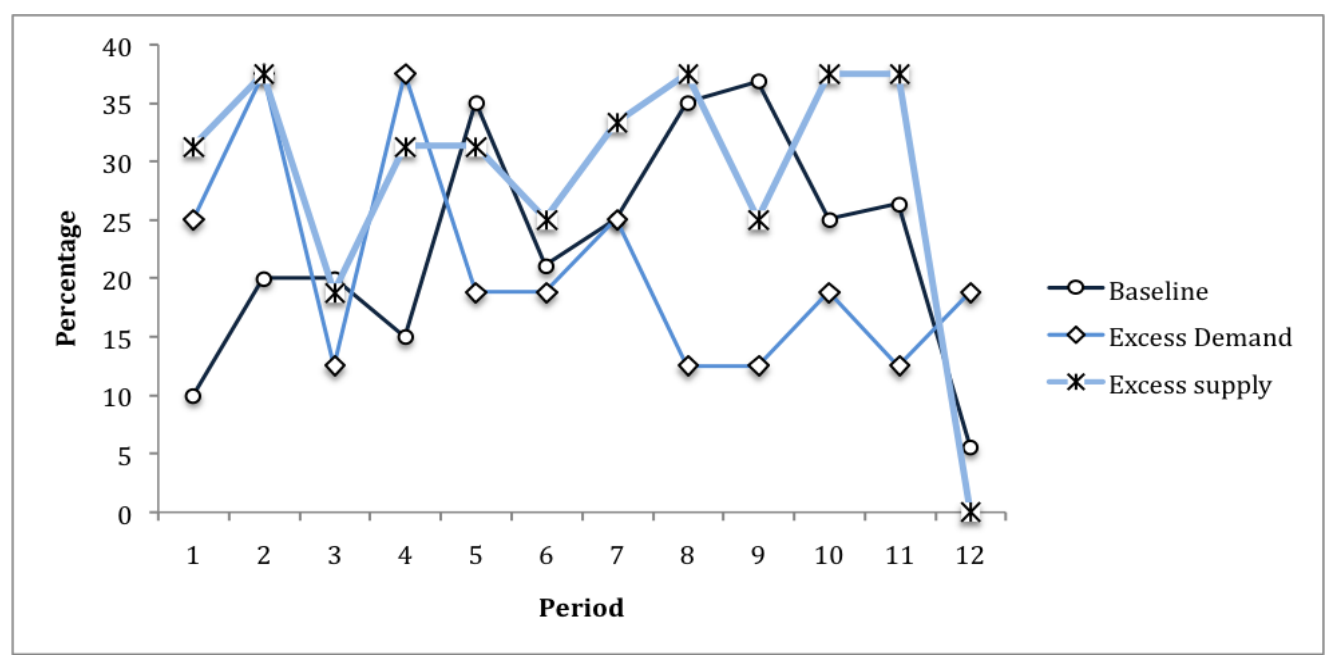

Fig.1. Evolution of the percentage of firms awarding thumbs over time and by market condition

Regarding the nature of contracts, firms should be indifferent between private and public offers. $59.19 \%$ of all accepted offers are private in the balanced market condition. The corresponding percentages are 52.33 in the excess demand condition and 67.25 in the excess 
supply condition. This ordering of the conditions suggests that firms are more indifferent when they do not expect much profit from a relationship. The use of symbolic rewards is more frequent in private contracts than when the contract results from a public offer. In the balanced market condition, $34.33 \%$ of private contracts are associated with the provision of thumbs while it is the case in only $8.82 \%$ of public contract offers. The corresponding percentages are $28.18 \%$ and $10.98 \%$ in the excess demand condition and $34.78 \%$ and $19.74 \%$ in the excess supply condition. ${ }^{12}$

Contrary to the standard predictions, employees choose a non-minimum level of effort on average and firms are more likely to give symbolic rewards to their employees when their level of effort is higher. Figure 2 displays the percentages of firms that give symbolic rewards for each level of effort in each condition. Figure A in Appendix shows the average number of thumbs given by effort level and market condition.

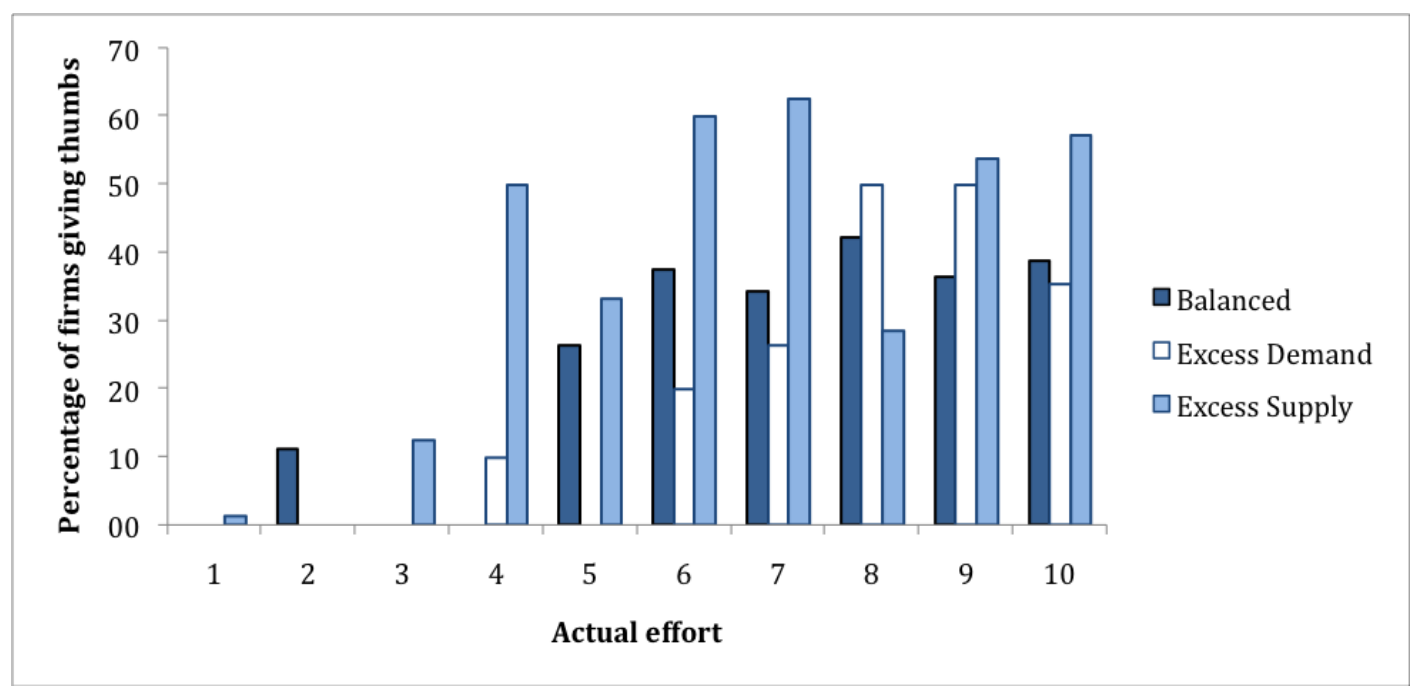

\footnotetext{
${ }^{12}$ As explained below Table 2, Wilcoxon signed-rank tests have been performed with each firm as a unit of observation. We average the number of thumbs each firm gives in each type of contract. Each firm yields one observation for its accepted private contracts and one observation for its accepted public contracts. The difference is significant in the balanced market condition $(p=0.013)$, but not in the excess demand condition ( $p$ $=0.328)$ or excess supply condition $(p=0.409)$.
} 
Fig.2. Percentage of firms giving symbolic rewards, by level of effort and by condition

Figure 2 and Figure A in Appendix show that in each condition, the higher the actual level of effort, the higher is the percentage of firms giving symbolic rewards and the number of thumbs assigned.

One behavioral prediction is that the provision of symbolic rewards should facilitate the creation of relational contracts and should therefore be associated with a longer average contract length. Figure 3 displays the relative frequency of employer-employee relationships initiated by symbolic rewards during the first period of interaction for three total duration categories and in each market condition.

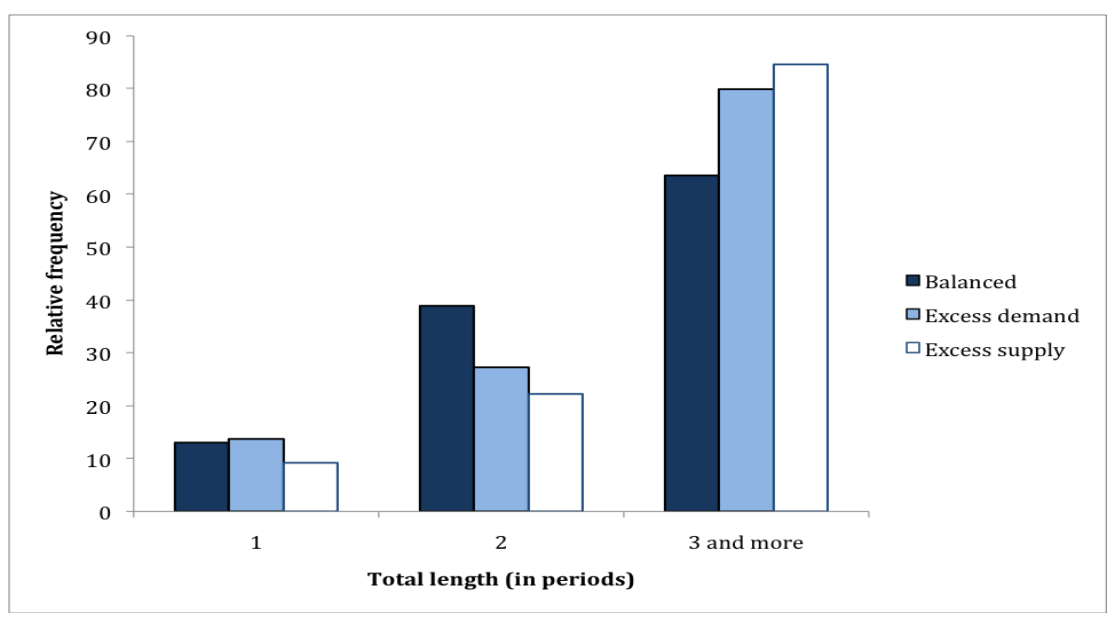

Fig.3. Proportion of relationships initiated by symbolic rewards, by total duration (number of periods) and market condition

Clearly, there is a positive association between the initial assignment of symbolic rewards and the construction of longer-term employment relationships under all market conditions. In the balanced condition, only $13.01 \%$ of the relationships that end after the first period of interaction gave rise to the provision of symbolic rewards. In contrast, in $63.64 \%$ of the relationships that lasted for at least three periods the firms sent symbolic rewards during the 
first period of interaction. This is even higher in the excess demand condition (80\%) and the excess supply condition (84.62\%), indicating that those firms that succeed in building relational contracts (i.e. longer-term contracts with the same employee) are likely to be the same as those that initially give non-monetary rewards to their employees.

This does not imply, however, that symbolic rewards are given throughout the duration of the relationship. Indeed, in the balanced condition, the percentage of firms giving symbolic rewards increases from $19.87 \%$ when the current contract length is 1 period, to $20.69 \%$ when it is 2 and $54.55 \%$ when it is 3, and the share decreases to $28.89 \%$ for longer current lengths. This is also observed in the excess demand condition (the corresponding percentages are $19.70,33.33,30$, and 12.5 , respectively) and the excess supply condition $(20.75,38.71$, 61.54 and 31.71, respectively). These patterns suggest that the firms use symbolic rewards not only to praise their employees for past effort but also strategically as a costly signaling device of their willingness to build long-term relationships: once the relationship is established, firms express respect less frequently.

\subsection{The determinants of firms' decisions to express respect}

Moving next beyond the bivariate relationships we considered above, we perform some regression analyses of the decisions made by the firm and employee subjects, respectively. We first analyze the determinants of the firms' decision to give symbolic rewards to their employees. We estimate five Probit models with robust standard errors and clustering at the individual level to control for the lack of independence between data. The dependent variable is the decision to assign symbolic rewards. In the first model, we only consider new relationships, i.e., current length is one period. The four next models consider all 
relationships, regardless of their current length, for all the conditions, the balanced market condition, the excess demand condition and the excess supply condition, respectively. This allows us to test whether different motivations are lying behind the decision to assign symbolic rewards when the employment relationship is new. The independent variables include the rent proposed to the employee (i.e., the difference between the wage offered and the cost of the suggested level of effort, indicating the generosity of the contract), a dummy variable for private contracts, the actual effort exerted by the employee, a dummy variable capturing that actual effort is equal or greater than the desired level of effort (the "no bad surprise" variable), and the gender of the employer. We also include a variable interacting the excess demand condition with the inability of the firm to conclude a contract in the previous period in order to test whether firms are more willing to use symbolic rewards when they are directly confronted with difficulties of recruitment. ${ }^{13}$ Moreover, a time trend is included to account for the evolution of behavior over time, as well as a dummy variable for the final period to control for a potential end game effect. ${ }^{14}$

We next estimate two linear regression models on pooled data, with robust standard errors and clustering at the individual level, in which the dependent variable is the number of thumbs given, conditional on the decision to assign thumbs. The first model considers only the new relationships and the second model accounts for all the relationships. The independent variables are the same as in the previous regressions, except that we exclude the time variables to identify the models and we include the inverse of the Mills ratio (IMR)

\footnotetext{
${ }^{13}$ This interacted variable would be irrelevant in the other market conditions as firms were almost always able to conclude a contract.

14 The period 12 variable is not included in the regression relative to the excess supply condition since no employer gave symbolic rewards in this period.
} 
given by the estimates of the selection equation to control for a potential selection bias. The results of these regressions are displayed in Table 3. The first five columns report the marginal effects from the Probit estimations and the last two columns contain the linear regression estimates. In each column, the numbers of observations correspond to the numbers of contracts accepted by the employees.

Table 3. Determinants of the employers' decisions

\begin{tabular}{|c|c|c|c|c|c|c|c|}
\hline \multirow{2}{*}{$\begin{array}{l}\text { Dependent } \\
\text { variables } \\
\text { Conditions }\end{array}$} & \multicolumn{5}{|c|}{ Decision to assign thumbs (Probit) } & \multicolumn{2}{|c|}{$\begin{array}{c}\text { Number of thumbs } \\
\text { assigned (OLS) }\end{array}$} \\
\hline & $\begin{array}{c}\text { All with } \\
\text { length=1 (1) }\end{array}$ & $\begin{array}{l}\text { All } \\
\text { (2) } \\
\end{array}$ & $\begin{array}{c}\text { Balanced } \\
\text { market } \\
(3)\end{array}$ & $\begin{array}{c}\text { Excess } \\
\text { demand } \\
(4)\end{array}$ & $\begin{array}{c}\text { Excess } \\
\text { supply (5) }\end{array}$ & $\begin{array}{l}\text { All with } \\
\text { length=1 } \\
(6)\end{array}$ & $\begin{array}{l}\text { All } \\
(7)\end{array}$ \\
\hline Rent proposed & -.002 & $-.005^{* *}$ & $-.009 *$ & .001 & -.004 & $-.040 * *$ & -.013 \\
\hline to the employee & $(.002)$ & $(.002)$ & $(.006)$ & $(.004)$ & $(.004)$ & $(.019)$ & $(.012)$ \\
\hline Private contract & $\begin{array}{l}.050 \\
(.032)\end{array}$ & $\begin{array}{l}.045 \\
(.037)\end{array}$ & $\begin{array}{l}.108^{*} \\
(.068)\end{array}$ & $\begin{array}{l}.056 \# \\
(.035)\end{array}$ & $\begin{array}{l}-.095 \\
(.077)\end{array}$ & $\begin{array}{l}-.084 \\
(.317)\end{array}$ & $\begin{array}{l}-.049 \\
(.316)\end{array}$ \\
\hline Actual effort & $\begin{array}{c}.063 * * * \\
(.010)\end{array}$ & $\begin{array}{c}.067 * * * \\
(.012)\end{array}$ & $\begin{array}{c}.075^{* * * *} \\
(.018)\end{array}$ & $\begin{array}{c}.054 * * * \\
(.020)\end{array}$ & $\begin{array}{l}.061 \\
(.021)\end{array}$ & $\begin{array}{l}.430 * * * \\
(.125)\end{array}$ & $\begin{array}{l}.223^{*} \\
(.123)\end{array}$ \\
\hline No bad surprise & $\begin{array}{l}.005 \\
(.036)\end{array}$ & $\begin{array}{l}.024 \\
(.058)\end{array}$ & $\begin{array}{l}-.073 \\
(.064)\end{array}$ & $\begin{array}{l}-.048 \\
(.056)\end{array}$ & $\begin{array}{l}.311 * * * \\
(.105)\end{array}$ & $\begin{array}{l}.747 * * \\
(.368)\end{array}$ & $\begin{array}{l}.679 * * \\
(.260)\end{array}$ \\
\hline $\begin{array}{l}\text { Balanced } \\
\text { market }\end{array}$ & $\begin{array}{l}-.066^{*} \\
(.036)\end{array}$ & $\begin{array}{l}-.046 \\
(.066)\end{array}$ & - & - & - & $\begin{array}{l}-.073 \\
(.431)\end{array}$ & $\begin{array}{l}-.027 \\
(.407)\end{array}$ \\
\hline $\begin{array}{l}\text { Excess demand } \\
\text { of labor }\end{array}$ & $\begin{array}{c}-.139 * * \\
(.036)\end{array}$ & $\begin{array}{l}-.105 \\
(.076)\end{array}$ & - & - & - & $\begin{array}{l}-.130 \\
(.655)\end{array}$ & $\begin{array}{l}.023 \\
(.568)\end{array}$ \\
\hline $\begin{array}{l}\text { No contract in } t \text { - } \\
1 \text { in Excess dem }\end{array}$ & $\begin{array}{l}.398 * * * \\
(.127)\end{array}$ & $\begin{array}{l}.394 * * * \\
(.129)\end{array}$ & - & $\begin{array}{c}.380 * * * \\
(.125)\end{array}$ & - & $\begin{array}{l}1.286^{*} \\
(.687)\end{array}$ & $\begin{array}{l}.405 \\
(.403)\end{array}$ \\
\hline Period & $\begin{array}{l}.007 \\
(007)\end{array}$ & $\begin{array}{l}-.011 * \\
(.007)\end{array}$ & $\begin{array}{l}-.003 \\
(.010)\end{array}$ & $\begin{array}{l}-.008 \\
(.009)\end{array}$ & $\begin{array}{c}-.030 * * * \\
(.011)\end{array}$ & - & - \\
\hline Period 12 & $\begin{array}{c}-.095 * * * \\
(.019)\end{array}$ & $\begin{array}{l}-.095 * \\
(.054)\end{array}$ & $\begin{array}{c}-.144 * * * \\
(.048)\end{array}$ & $\begin{array}{l}.037 \\
(.120)\end{array}$ & - & . & - \\
\hline Male employer & $\begin{array}{c}-.067 * * \\
(.029)\end{array}$ & $\begin{array}{l}-.088 \# \\
(.054)\end{array}$ & $\begin{array}{l}-.067 \\
(.083)\end{array}$ & $\begin{array}{l}-.071 \\
(.061)\end{array}$ & $\begin{array}{l}-.185^{*} \\
(.110)\end{array}$ & $\begin{array}{l}-.158 \\
(.440)\end{array}$ & $\begin{array}{l}-.064 \\
(.379)\end{array}$ \\
\hline IMR & - & - & - & - & - & $\begin{array}{l}.179 * * \\
(.069)\end{array}$ & $\begin{array}{l}.006 \\
(.004)\end{array}$ \\
\hline Constant & - & - & - & - & - & $\begin{array}{l}-388 \\
(.682)\end{array}$ & $\begin{array}{l}.607 \\
(.853) \\
\end{array}$ \\
\hline $\mathrm{N}$ & 378 & 603 & 236 & 176 & 191 & 75 & 146 \\
\hline Log pseudo-L. & -110.225 & -248.551 & -97.970 & -60.691 & -72.798 & - & - \\
\hline Pseudo- $\mathrm{R}^{2} / / \mathrm{R}^{2}$ & .415 & .255 & .235 & .319 & .365 & .306 & .211 \\
\hline F / Prob $>F$ & - & - & - & - & - & $5.09 / .000$ & $4.26 / .000$ \\
\hline Wald $\mathrm{Chi}^{2}$ & 117.02 & 75.42 & 72.19 & 37.73 & 19.74 & - & - \\
\hline Prob $>\mathrm{Chi}^{2}$ & .000 & .000 & .000 & .000 & .003 & - & - \\
\hline
\end{tabular}


Note: Models 1 to 5 are Probit models with robust standard errors (in parentheses) and clustering at the individual level. Marginal effects are reported. Models 6 and 7 estimate the second equation in a two-step estimation procedure (the first equation is estimated by means of the previous Probit models). They are estimated by means of OLS models with robust standard errors and clustering at the individual level and they include the inverse of the Mill's ratio as a dependent variable to control for a potential selection bias. *, **, and *** indicate statistical significance at the $0.10,0.05$, and 0.01 level, respectively. \# indicates significance at the $11 \%$ level. The numbers of observations correspond to the numbers of contracts accepted by employees (for example 236 out of 240 offers in the Baseline treatment, or 191 out of 192 offers in the Excess supply treatment). In the regressions in which we include the "No contract in $t-1$ in Excess demand condition" variable, period 1 of the excess demand condition is not included.

As indicated in the first two columns of Table 3, the likelihood that a firm assigns thumbs to an employee increases by $6.28 \%$ for each additional unit of effort exerted by a new employee and by $6.74 \%$ if one considers all interactions. This is true regardless of whether or not the employee follows the firm's suggested level of effort. We also find that the likelihood of assigning thumbs is declining over time, especially in the final period of the game and it is lower for male employers.

The last two columns of Table 3 confirm that, conditional of assigning thumbs and controlling for the level of the rent, the number of thumbs assigned consistently increases in the employee's actual level of effort but it is also significantly higher when the employee is reciprocal and delivers a level of effort that is equal or higher than the suggested level of effort. There is also some evidence of a trade-off between the generosity of the contract, as measured by the rent, and the number of thumbs, which is significant for new relationships.

There are notable differences between the market conditions. First, regarding new relationships (column (1)), the likelihood of assigning symbolic rewards decreases by $6.56 \%$ when the market is balanced and by $13.92 \%$ in the excess demand condition, both relative to the excess supply condition and controlling for the actual levels of effort. This makes sense as the profits that can be earned in the excess demand condition are lower than in the other 
conditions (see Table 2). However, in this condition, having experienced inactivity in the previous period increases the likelihood that a firm will offer symbolic rewards in the current period by $39.78 \%$ (column (1)) and the number of thumbs assigned by $1.29 \%$ (column (6)). This suggests that thumbs are used to increase the likelihood of forming a relationship. At the same time, the fact that in this condition the final period is not significant suggests that some firms use thumbs up to the last period, i.e. non-strategically, to reward their employee for having accepted a contract.

A second difference is that there is some evidence of a substitution effect between monetary and non-monetary rewards, significant in the pooled regression (column (2)) and in the balanced market condition (column (3)). In this condition, each additional unit of rent offered by the firm decreases the likelihood that a firm assigns thumbs by $0.91 \%$. There is no significant substitution effect between rent and thumbs in the other conditions. In the excess demand treatment, this may be due to the fact that firms face a higher risk of not being able to hire any worker. In the excess supply condition, firms can offer lower rents on average due to the competition between employees and therefore they have less pressure to substitute monetary and non-monetary rewards. Third, while the likelihood of assigning thumbs increases significantly in the actual level of effort in both the balanced market and the excess demand conditions, the assignment of thumbs in the excess supply condition is triggered by the provision of a level of effort equal or higher than that suggested by the firm.

To investigate further the role of symbolic rewards as a coordination device, we now study whether assigning thumbs is associated with the employers' willingness to keep the same employee in the next period. We estimate Probit models with robust standard errors and 
clustering at the individual level in which the dependent variable is the probability for an employer to make a private offer to the same employee as in the previous period. The independent variables include the effort provided by the employee in the previous period and a dummy variable indicating whether this level of effort was equal or higher than that suggested by the firm. In columns (2) to (5), we include a dummy variable indicating that the firm has assigned at least one thumb in $t-1$. A time trend is also included and we control for final period and gender. Table 4 displays the results. The model in column (1) considers the baseline treatment. The model in column (2) pools the data of all conditions of the respect treatment and includes dummy variables for the balanced market and the excess demand conditions. Columns (3) to (5) display the estimates for the balanced market, the excess demand and the excess supply conditions, respectively.

Table 4. Determinants of the employer's probability to make a private offer to same employee as in the previous period

\begin{tabular}{|c|c|c|c|c|c|}
\hline \multirow{2}{*}{$\begin{array}{l}\text { Treatments and } \\
\text { conditions }\end{array}$} & \multirow[b]{2}{*}{$\begin{array}{l}\text { Baseline } \\
\text { treatment } \\
\text { (1) }\end{array}$} & \multicolumn{4}{|c|}{ Respect treatment } \\
\hline & & $\begin{array}{c}\text { All } \\
\text { conditions } \\
(2)\end{array}$ & $\begin{array}{c}\text { Balanced } \\
\text { market } \\
(3)\end{array}$ & $\begin{array}{c}\text { Excess } \\
\text { demand } \\
\text { (4) }\end{array}$ & $\begin{array}{c}\text { Excess } \\
\text { supply } \\
(5)\end{array}$ \\
\hline Effort in $t-1$ & $\begin{array}{c}.048^{* * * *} \\
(.019)\end{array}$ & $\begin{array}{c}.110^{* * * *} \\
(.014)\end{array}$ & $\begin{array}{c}.104 * * * \\
(.025)\end{array}$ & $\begin{array}{c}.105 * * * \\
(.023)\end{array}$ & $\begin{array}{c}.134^{* * * *} \\
(.021)\end{array}$ \\
\hline $\begin{array}{l}\text { No bad surprise } \\
\text { in } t-1\end{array}$ & $\begin{array}{c}.366^{* * * *} \\
(.085)\end{array}$ & $\begin{array}{l}.026 \\
(.069)\end{array}$ & $\begin{array}{l}.179 \\
(.119)\end{array}$ & $\begin{array}{l}.026 \\
(.130)\end{array}$ & $\begin{array}{l}-.174 \\
(.157)\end{array}$ \\
\hline $\begin{array}{l}\text { Assignment of } \\
\text { thumbs in } t-1\end{array}$ & - & $\begin{array}{c}.208 * * * \\
(.074)\end{array}$ & $\begin{array}{l}.304 * * \\
(.136)\end{array}$ & $\begin{array}{l}.088 \\
(.133)\end{array}$ & $\begin{array}{l}.263^{*} \\
(.142)\end{array}$ \\
\hline Balanced market & $\begin{array}{l}-.033 \\
(.113)\end{array}$ & $\begin{array}{c}-.171 * * \\
(.076)\end{array}$ & - & - & - \\
\hline $\begin{array}{l}\text { Excess demand } \\
\text { of labor }\end{array}$ & $\begin{array}{c}-.364 * * \\
(.165)\end{array}$ & $\begin{array}{l}-.102 \\
(.081)\end{array}$ & - & - & - \\
\hline Period & $\begin{array}{l}.005 \\
(.011)\end{array}$ & $\begin{array}{c}.042 * * * \\
(.012)\end{array}$ & $\begin{array}{l}.040 * * \\
(.019)\end{array}$ & $\begin{array}{l}.036^{*} \\
(.019)\end{array}$ & $\begin{array}{l}.050^{*} \\
(.026)\end{array}$ \\
\hline Period 12 & $\begin{array}{l}-.048 \\
(.089)\end{array}$ & $\begin{array}{l}-.097 \\
(.102)\end{array}$ & $\begin{array}{l}.112 \\
(.182)\end{array}$ & $\begin{array}{l}-.138 \\
(.103)\end{array}$ & $\begin{array}{c}-.364 * * \\
(.162)\end{array}$ \\
\hline Male employer & $\begin{array}{l}-.037 \\
(.130) \\
\end{array}$ & $\begin{array}{c}-.147 * * \\
(.072) \\
\end{array}$ & $\begin{array}{l}-.056 \\
(.134) \\
\end{array}$ & $\begin{array}{c}-.255^{* * * *} \\
(.091) \\
\end{array}$ & $\begin{array}{l}-.067 \\
(.113) \\
\end{array}$ \\
\hline $\mathrm{N}$ & 268 & 568 & 217 & 176 & 175 \\
\hline
\end{tabular}




\begin{tabular}{|c|c|c|c|c|c|}
\hline Log likelihood & -133.881 & -225.426 & -82.079 & -77.338 & -59.303 \\
\hline Wald $\mathrm{Chi}^{2}$ & 45.64 & 165.59 & 78.25 & 67.67 & 81.51 \\
\hline $\mathrm{p}>\mathrm{Chi}^{2}$ & .000 & .000 & .000 & .000 & .000 \\
\hline Pseudo $\mathrm{R}^{2}$ & .279 & .423 & .438 & .364 & .511 \\
\hline
\end{tabular}

Note: These regressions estimate Probit models with robust standard errors (in parentheses) and clustering at the firm level. The table reports the marginal effects. $*, * *$, and $* * *$ indicate statistical significance at the 0.10 , 0.05 , and 0.01 level, respectively. The numbers of observations correspond to the firms who concluded a contract with an employee in the previous period.

Each additional unit of effort in $t-1$ increases the likelihood that a firm makes an offer to the same employee by $4.82 \%$ in the baseline treatment and by $11 \%$ in the respect treatment. In addition, in the baseline treatment providing at least the effort suggested by the firm increases the probability of offering to continue the employment relationship by $36.62 \%$. This variable is not significant in the respect treatment but its effect may be indirect and express itself through the assignment of thumbs. Assigning thumbs in the previous period increases the probability of making a private offer to the same employee in the current period by $20.78 \%$, which indicates the role of symbolic rewards in the willingness to establish relational contracts. However, the strength of the link between assigning thumbs and making a private offer to the same employee differs across treatments. Models (3) to (5) indicate that the corresponding marginal effect is $30.39 \%$ in the balanced market condition and $26.34 \%$ in the excess supply condition but it is not statistically significant in the excess demand condition. In the baseline treatment with excess demand of labor, firms are less likely to make an offer to their previous employee to prolong their relationship, probably because this relationship is less profitable than in the excess supply condition. In contrast, in the respect treatment under this market condition, firms are not less likely to make a private offer to the same employee than in the excess supply condition. An interpretation is that firms that did not offer symbolic thumbs fear the competition from other firms offering 
potentially such rewards and are more likely to offer private contracts to the same employee than in the baseline treatment to increase their chance of contracting (see also table 2). This could explain that in this market condition, offering thumbs is not distinctive for the likelihood of making a private offer to the same employee.

\subsection{Do employees value respect?}

To understand whether the receipt of symbolic rewards influences the employee's willingness to continue the employment relationship and to exert additional effort, we estimate a two-step selection model to correct for potential selection bias. A selection (Probit) equation estimates the probability that an employee is working in the same firm as in the previous period after receiving a private offer from this firm. The independent variables include market condition dummies (with the excess supply condition as the reference category), the rent offered to the employee in $t-1$, the number of thumbs received in $t-1$, this variable being also interacted with each market condition, a time trend, a dummy variable for the final period, and the employee's gender. Column (1) in Table 5 reports the marginal effects of these variables. The second equation analyzes the determinants of the difference in the effort levels between the current period and the previous one conditional on having accepted a private offer from the same firm. This incorporates the inverse of the Mills ratio (IMR) extracted from the selection equation. We omit the rent variable to identify the model but include the change in the rent between the current and the previous period. In all the regressions, standard errors are robust and clustered at the individual level. 
Table 5. Determinants of the employee's behavior

\begin{tabular}{lcc}
\hline Dependent variables & $\begin{array}{c}\text { Probability of working } \\
\text { in the same firm as in } t- \\
1 \text { after a private offer } \\
(1)\end{array}$ & $\begin{array}{c}\text { Change in effort between } t \text { and } \\
t-1 \text { conditional on accepting an } \\
\text { offer from the same firm }\end{array}$ \\
\hline Balanced market & $-.064(.086)$ & $(2)$ \\
Excess demand & $-.410^{* * *}(.150)$ & $.114(.421)$ \\
Rent proposed to the employee in $t-1$ & $.006^{* * *}(.002)$ & $.463(.485)$ \\
Change in rent between $t$ and $t-1$ & - & - \\
Nb thumbs received in $t-1$ & $.077 * * *(.028)$ & $.141^{* * *}(.023)$ \\
Nb thumbs received in $t-1$ in Balanced & $-.048(.039)$ & $-.192(.130)$ \\
market & & $.344 * *(.163)$ \\
Nb thumbs received in $t-1$ in Excess & $-.021(.034)$ & $.145(.152)$ \\
demand & & \\
Period & $.029 * * *(.007)$ & $-.007(.054)$ \\
Period 12 & $-.133(.126)$ & $-2.294 * *(.720)$ \\
Male employee & $-.015(.065)$ & $.252(.227)$ \\
IMR & - & $-.345(.504)$ \\
Constant & - & $-.508(.743)$ \\
\hline $\mathrm{N}$ & 252 & 203 \\
Log Likelihood & -96.693 & - \\
Wald Chi ${ }^{2} / / \mathrm{F}$ & 50.30 & 7.92 \\
Prob $>$ Chi $^{2} / />\mathrm{F}$ & 0.000 & 0.000 \\
Pseudo $\mathrm{R}^{2} / / \mathrm{R}^{2}$ & 0.230 & 0.399 \\
\hline
\end{tabular}

Note: Column (1) reports the marginal effects resulting from the estimation of a Probit model. Column (2) reports an OLS regression with a correction for a potential selection bias. All standard errors (in parentheses) are robust and clustered at the employee level. ** and *** indicate statistical significance at the 0.05 and 0.01 level, respectively. The numbers of observations correspond to the employees who received a contract offer from the firm employing them in the previous period.

Ceteris paribus, each thumb received in the previous period increases the likelihood that the employee chooses to work in the same firm in the subsequent period after receiving a private offer from this firm by $7.66 \%$, the equivalent of 12.83 points of rent (column 1 ). ${ }^{15}$ Thumbs

15 To test whether not receiving thumbs for a low effort in the previous period reduces the probability that an employee is willing to work in the same firm in the current period, we have estimated another Probit model (available upon request). The dependent variable takes value 1 if the employee is working in the same firm as in $\mathrm{t}-1$ and 0 otherwise. The data of all treatments and conditions are pooled together but we restrict the sample to employees who provided a level of effort lower than $4(\mathrm{~N}=263)$. The independent variables include a variable interaction of the respect treatment with the assignment of no thumb in $t-1$. The results show that the absence of thumbs for a low effort decreases the likelihood of an employee to work in the same firm compared with the baseline treatment. This variable is significant at the $10 \%$ level but its marginal effect is not significant 
have a similar impact regardless of the labor market condition. However, when there is excess demand of labor on the market, employees are less likely to be willing to prolong the relationship than in the other conditions since it is easier to switch firms. The time trend is significant and positive, capturing the development of relational contracts over time.

Conditional on working in the same firm, the influence of receiving thumbs in the previous period on the evolution of effort between $t$ and $t-1$ is only significant in the balanced market condition. In this condition, each thumb received leads to an increase in effort by $34.37 \% .^{16}$ One can also note that in the final period, the change in effort is negative, indicating the presence of a strong end game effect.

The findings from the regressions reported in Table 5 imply that employees value the receipt of symbolic rewards when choosing their employer, also after controlling for the generosity of the offer. This finding is confirmed by the analysis of the firms" "popularity index". This index is given by the number of times the identification number of the firm has been cited by employees when asked to indicate which firm they would like to receive an offer from. The higher the total number of thumbs awarded by a firm, the higher is its popularity index. ${ }^{17}$

\subsection{Is paying respect profitable?}

at the conventional level (14\%). This suggests that not assigning symbolic rewards when it is possible to do so tends to exert a detrimental but modest effect on the likelihood of continuing a relationship.

\footnotetext{
16 The various impacts of the symbolic rewards by market condition is robust to several specification changes (i.e., omitting the time trend instead of the rent to identify the model, including both the rent and the time trend, or estimating in the first stage the probability to work in the same firm as previously regardless of whether the firm has made a private offer to the employee in the current period).

17 This result comes from a Tobit regression analysis (available upon request) in which the popularity index of each firm is the dependent variable ( $\mathrm{N}=89$ and not 90 as one firm was never able to recruit an employee). The independent variables include the average rent offered by the firm when contracting, the total number of thumbs awarded by the firm in the respect treatment, and dummy variables for the balanced market and the excess demand conditions. Popularity increases in the average rent offered (coefficient=.146, significant at the $1 \%$ level) and in the number of thumbs awarded (coefficient=.100, significant at the $6 \%$ level).
} 
To look at the overall impact of provision of symbolic rewards on firms' profits, we compare average profits in the respect treatment and in the baseline treatment. In the balanced market condition, the average profit is 13.82 points in the baseline treatment and 15.26 points in the respect treatment (see Table 2). In the latter, if we only consider firms having an employee, the average profit amounts to 29.69 points for firms using symbolic rewards and 11.22 for the others. In the excess demand condition, the corresponding values are respectively 0.15 and $1.64,21.4$ and -2.51 . In the excess supply condition, the respective values are 21.16 and $14.10,35.35$ and 5.62. It is clear that the respect treatment does not generate higher profits than in the baseline treatment in most market conditions.

This fact may be partly driven by the offer of less generous contracts to employees. Indeed, regardless of the market condition, the average rent offered to employees is lower in the respect treatment than in the baseline (see Table 2). This is true even in the first period: when the market is balanced, the rent amounts to 34.11 in the baseline and 30.75 in the respect treatment; the corresponding numbers are 68.25 and 54 in the excess demand condition, and 35.13 and 28.75 in the excess supply condition. The offer of lower rents may be due to a substitution effect between rents and symbolic rewards (as shown in Table 3 for the balanced market condition). This substitution effect may have exerted a general depressing effect on the rents offered to employees on the market. The consequence of less generous contracts is that average effort levels, and therefore profits, are lower, due to reciprocity concerns.

However, controlling for the rent, the period, the final period and the employer's gender, we still find that the profit level is significantly lower in the respect treatment than in the 
baseline in the excess supply condition and there is no significant difference in the other conditions (regressions available upon request). A potential explanation is that profits cannot be higher in the respect treatment compared with the baseline if the assignment of no thumb in the previous period leads to a downward adjustment of effort that is not offset by an increase of effort generated by the assignment of thumbs. We have estimated linear regressions with robust standard errors clustered at the firm level in which the dependent variable is the change in the firm's profit between the previous and the current periods in the respect treatment, conditional on employing the same employee in both periods (available upon request). Controlling for the change in the rent between $t$ and $t-1$, a time trend, and dummy variables for the final period and the employer's gender, the assignment of no thumb in $t-1$ reduces the profit between the two periods by 4.69 points in the balanced market condition (significant at the 5\% level). In a similar regression including instead the number of thumbs assigned in $t-1$, we find that each thumb increases the profit in $t$ by 1.28 point (significant at the $6 \%$ level). Since a majority of firms do not assign thumbs, the detrimental effect of not expressing praise when it was possible to do it could limit the ability of the respect treatment to generate higher profits when the market is balanced. In the other conditions, the assignment of no thumbs in $t-1$ and the number of thumbs assigned do not impact the variation of profits significantly. This is consistent with Table 5 indicating that symbolic rewards do not increase effort in continuing relationships when the bargaining power between firms and employees is unequal. It seems that in the excess supply condition, the addition of symbolic rewards for a higher effort to such an unequal bargaining power creates an environment that is detrimental to the employees' positive reciprocity. 


\section{DISCUSSION AND CONCLUSION}

Our repeated three-stage gift exchange game delivers some notable findings regarding the use of non-monetary rewards. We find that a sizable fraction of our firm-participants make use of the opportunity to express respect to their employees although the employment relationship is terminated at the end of each period. Respect is expressed as a response to the employee's higher effort. In this sense, it is backward-looking. But it is also forwardlooking as symbolic rewards are used as a signaling and coordination device to initiate relational contracts. Indeed, the firms giving symbolic rewards are more likely to make a private offer to the same employee in the next period aiming at hiring him again. When the labor market is not balanced, we also find that symbolic rewards are more used when the firm was not able to contract in the previous period and they become less used once it is clear that the relational contract is established.

Controlling for the rent offered in the previous period, employees are more willing to accept a job offer from the same employer when the employer paid respect to him in previous periods. This is observed in all conditions. In contrast, when the employment relationship is continued the impact of symbolic rewards on further effort depends on the competition for employees in the market. Indeed, employees are more willing to increase their effort further only when the market is balanced. An interpretation is that when there is excess supply, employees understand that the employers use symbolic rewards to prolong a more valuable 
relationship, which should decrease their risk of unemployment; when there is excess demand, their bargaining power is stronger as they can more easily switch to another firm.

A puzzling finding of our study is that when firms have the opportunity to express respect to their employees, profits are not improved. Overall, when firms have the opportunity to express respect, the mean rent offered to the employees is significantly lower. This suggests that for some employers, monetary and non-monetary incentives are used as substitutes and not as complements. In addition, it may be difficult for the employees to interpret the intentions of the employers that award symbolic rewards, especially when the two parties have a strongly asymmetric bargaining power.

We think of at least four extensions of our work. First, in our experiment symbolic rewards can be used both to build relational contracts and to praise employees. It would be interesting to study the extent to which employers would express respect when the continuity of the relationship is guaranteed. Second, in our experiment expressing respect is cheap. It is unclear whether a higher cost of symbolic rewards would decrease or increase their use. On the one hand, if expressing respect becomes more costly, firms may be less willing to pay for it. But on the other hand, if a higher cost indicates to both employers and employees that these rewards are more valuable, it may increase their signaling value and firms may be more willing to award these symbolic rewards to their more productive employees. A third possible extension would consist of awarding symbolic rewards in public. Indeed, in our experiment symbolic rewards remain private information between the firm and the employee. If private recognition is important because it motivates people to feel good about themselves, public recognition may be also valued because people like that their colleagues 
think highly of them. This extension would allow us to test how different information conditions change the way firms pay respect to their employees. Finally, giving the firms the possibility to express either or both approval and disapproval is also a natural extension of the current study. ${ }^{18}$ It would allow us to test whether employees work harder to avoid disapproval than to get approval and whether firms buy more disapproval points than approval points if they anticipate that individuals are more affected by receiving disapproval than approval. In the context of public goods games, it has been shown that the combination of both monetary sanctions and rewards increases contributions more than using each device separately (Sefton, Schupp, and Walker, 2007). The relative efficiency of symbolic rewards and sanctions remains an interesting issue to explore.

${ }^{18}$ For an analysis of approvals and disapprovals in the context of a coordination game, see Dugar (2010). 


\section{References}

Ariely, D., A. Bracha, and S. Meier (2009), «Doing Good or Doing Well ? Image Motivation and Monetary Incentives in Behaving Prosocially», American Economic Review 99(1), 544-555

Ball, S., C.E. Eckel, P.J. Grossman, and W. Zame (2001), «Status in Markets », Quarterly Journal of Economics 116(1), 161-188

Benabou, R. and J. Tirole (2002), «Self-Confidence and Personal Motivation », Quarterly Journal of Economics 117(3), 871-915.

Benabou, R. and J. Tirole (2006), «Incentives and Prosocial Behavior», American Economic Review 96(5), 1652-1678.

Bolton, G., E. Katok, and A. Ockenfels (2004), «How Effective are Electronic Reputation Mechanisms? An Experimental Investigation», Management Science 50(11), 15871602.

Brown, M., A. Falk, and E. Fehr (2004), «Relational Contracts and the Nature of Market Interactions», Econometrica 72(3), 747-780.

Camerer, C. and U. Malmendier (2007), « Behavioral Economics and Organizations », in P. Diamond and H. Vartiainen (eds.), Behavioral Economics and Its Applications. Princeton University Press, 235-281

Carpenter, J. and E. Seki (2010), «Do Social Preferences Increase Productivity? Field Experimental Evidence from Fishermen in Toyoma Bay», forthcoming in Economic Inquiry.

Charness, G. (2004), «Attribution and Reciprocity in an Experimental Labor Market», Journal of Labor Economics 22(3), 665-688.

Charness, G., and P. Kuhn (2011). «Lab Labor: What Can Labor Economists Learn from the Lab?», in D. Card and O. Ashenfelter (eds.), Handbook of Labor Economics, Volume $4 A, 229-330$

Charness, G., Masclet, D., and Villeval, M.C. (2010). «Competitive Preferences and Status as an Incentive: Experimental Evidence», IZA Discussion Paper 5034, Bonn.

Cottini, E., T. Kato, and N. Westergaard-Nielsen (2009). «Adverse Workplace Conditions, High-Involvement Work Practices and Labor Turnover: Evidence from Danish Linked Employer-Employee Data», IZA Discussion Paper 4587, Bonn.

Dana, J., D.M. Cain, and R.M. Dawes (2006). «What You Don’t Know Won't Hurt Me : Costly but Quiet Exit in Dictator Games», Organizational Behavior and Human Decision Processes 100(2), 193-201.

Dickinson, D. and MC Villeval (2008), «Does Monitoring Decrease Work Effort ? The Complementarity between Agency and Crowding-out Theories», Games and Economic Behavior 63, 56-76. 
Dugar, S. (2010), «Nonmonetary Sanctions and Rewards in An Experimental Coordination Game», Journal of Economic Behavior \& Organization 73(3), 377-386

Ellingsen, T., and M. Johannesson (2007a), «Paying Respect», Journal of Economic Perspectives 21(4), 135-149.

Ellingsen, T., and M. Johannesson (2007b), «Verbal Feedback Induces Prosocial Behavior» Mimeo.

Ellingsen, T., and M. Johannesson (2008), «Pride and Prejudice: The Human Side of Incentive Theory », American Economic Review 98, 990-1008

Falk, A., and M. Kosfeld (2006), «The Hidden Costs of Control», American Economic Review 96(5), 1611-1630.

Fehr, E. and A. Falk (2002), «Psychological Foundations of Incentives», European Economic Review 46, 687-724.

Fehr, E., S. Gächter, and G. Kirchsteiger (1997), «Reciprocity as Contract Enforcement Device», Econometrica 65, 833-860

Fehr, E., G. Kirchsteiger, and A. Riedl (1993), «Does Fairness Prevent Market Clearing? An Experimental Investigation», Quarterly Journal of Economics 108 (2), 437-59.

Fehr, E., A. Klein, and K. Schmidt (2007), «Fairness and Contract Design», Econometrica 75(1), 121-154.

Fehr, E., and K. Schmidt (1999). «A Theory of Fairness, Competition and Co-operation", Quarterly Journal of Economics 114, 817-868.

Gaines, L.M., J. Duvall, J.M. Webster, and R.H. Smith (2005). «Feeling Good after Praise for a Successful Performance : The Importance of Social Comparison Information», Self and Identity 4, 373-389.

Gneezy, U. and A. Rustichini (2000), «Pay Enough or Don’t Pay at All», Quarterly Journal of Economics 115(3), 791-810.

Gostick, A. and C. Elton (2004). «A Carrot a Day: A Daily Dose of Recognition for Your Employees». Gibbs Smith.

Greiner B. (2004), «An Online Recruitment System for Economic Experiments, » in: Kurt Kremer, Volker Macho (Eds), Forschung und Wissenschaftliches Rechnen 2003. GWDG Bericht 63; Göttingen: Ges. für Wiss. Datenverarbeitung, 79-93.

Kandel, E. And E.P. Lazear (1992). «Peer Pressure and Partnerships», Journal of Political Economy 100(4), 801-817

Kirchsteiger, G., M. Niederle, and J. Potters (2001). «Public versus Private Exchanges», CENter Discussion paper $n^{\circ} 2001-101$.

Kosfeld, M. and S. Neckermann (2011), «Getting More Work for Nothing? Symbolic Awards and Worker Performance», American Economic Journal : Microeconomics, forthcoming.

Lazear, E.P. and K.L. Shaw (2007). «Personnel Economics: The Economist's View of 
Human Resources», Journal of Economic Perspectives 21(4), 91-114.

Morris, D., P. Collett, P. Marsh, and M. O'Shaughness (1979). Gestures: Their Origin and Meanings. London: Cape.

Rebitzer, J. and L. Taylor (2011), «Extrinsic Rewards and Intrinsic Motives: Standard and Behavioral Approaches to Agency and Labor Markets», in D. Card and O. Ashenfelter (eds.), Handbook of Labor Economics, Volume 4A, 701-772.

Rhoades, L. and R. Eisenberger (2002). «Perceived Organizational Support: A Review», Journal of Applied Psychology 87, 698-714.

Sefton, M., R. Shupp, and J.M. Walker (2007). «The Effect of Rewards and Sanctions in Provision of Public Goods», Economic Inquiry, 45(4), 671-690.

Webster, J.M., J. Duvall, L.M. Gaines, and R.H. Smith (2003). «The Roles of Praise and Social Comparison Information in the Experience of Pride», Journal of Social Psychology 143, 209-232.

Xiao, E. and D. Houser (2007), «Emotions Expression and Fairness in Economic Exchange», ICES Working Paper, Washington D.C.

Zeiliger R. A Presentation of Regate, Internet Based Software or Experimental Economics. http://www.gate.cnrs.fr/ zeiliger/regate/RegateIntro.ppt., GATE; 2000. 


\section{Appendix. Instructions for the balanced respect treatment (other instructions are available upon request)}

We thank you for participating in this experiment. At the beginning of this session, you will receive an initial endowment of 5 Euros. During the course of this experiment, you can earn a further amount of money by accumulating points. The amount of points that you gain during the experiment depends on your decisions and the decisions of other participants. All the points that your will earn during the 12 periods of this experiment will be summed and exchanged into Euros at the end of the experiment according to the exchange rate of :

$$
100 \text { points }=4 \text { Euros }
$$

At the end of the experiment, you will receive the amount that you earned during this experiment in addition to your initial endowment. Your earnings will be paid in cash in a separate room.

There are two roles in this experiment: there are employers and employees. The role of each participant is randomly allocated at the beginning of the experiment and each will keep the same role during the whole experiment. The number of employers is the same as the number of employees.

All participants have received an identification number which they will keep for the entire experiment. You will find your number on your screen.

\section{Overview of each period}

In each period, every employer can recruit one employee. The procedures are as follows.

1. Each period starts with a trading phase which lasts 3 minutes. During this phase, employers can submit contract offers which can be accepted by employees. When submitting an offer, the employer has to specify three things:

- which wage he offers

- which quality of work he desires

- and whether he wants to submit public offers to all employees or private offers to specific employees only.

Offers can be accepted by employees at any time during the trading phase. his work.

2. Following the trading phase, each employee who has concluded a trade chooses the actual quality of

3. After being informed on the quality of work chosen by his employee, the employer can decide to express his approval to his employee by means of signs of approval.

4. Lastly, each participant's earnings in the current period are determined.

\section{Description of each stage}

\section{The trading phase on the market}

Each period starts with a trading phase that lasts a maximum of 3 minutes. During this stage, each employer can conclude a contract with an employee. In order to do so, he can submit as many offers as he wishes.

Each employer can see the following screen: 
Période: 3/12 Temps: 163 secondes

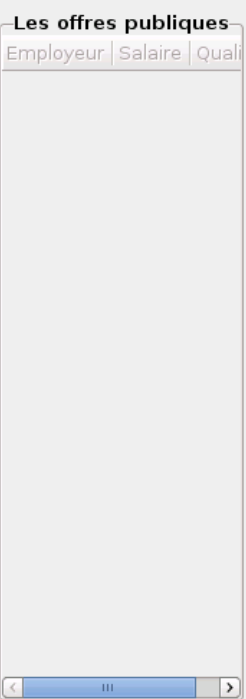

Vous êtes l'employeur 1

vos offres privées

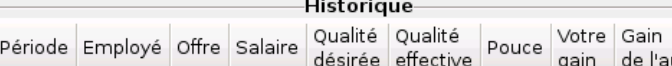

Salaire| Qualité| Employ

Les employés actuellement sur le marché:

[1] gain de l'autre désirée effective

0

○ offre publique

Quel salaire proposez-vous ?

0

offre privée

Quel est le numéro de

l'employé à qui vous

faites une offre privée ?

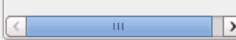

(
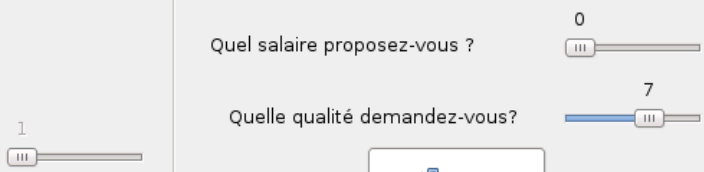

Quelle qualité demandez-vous?

$\leftrightarrow \underline{v}$ alider

Each employee can see the following screen: 

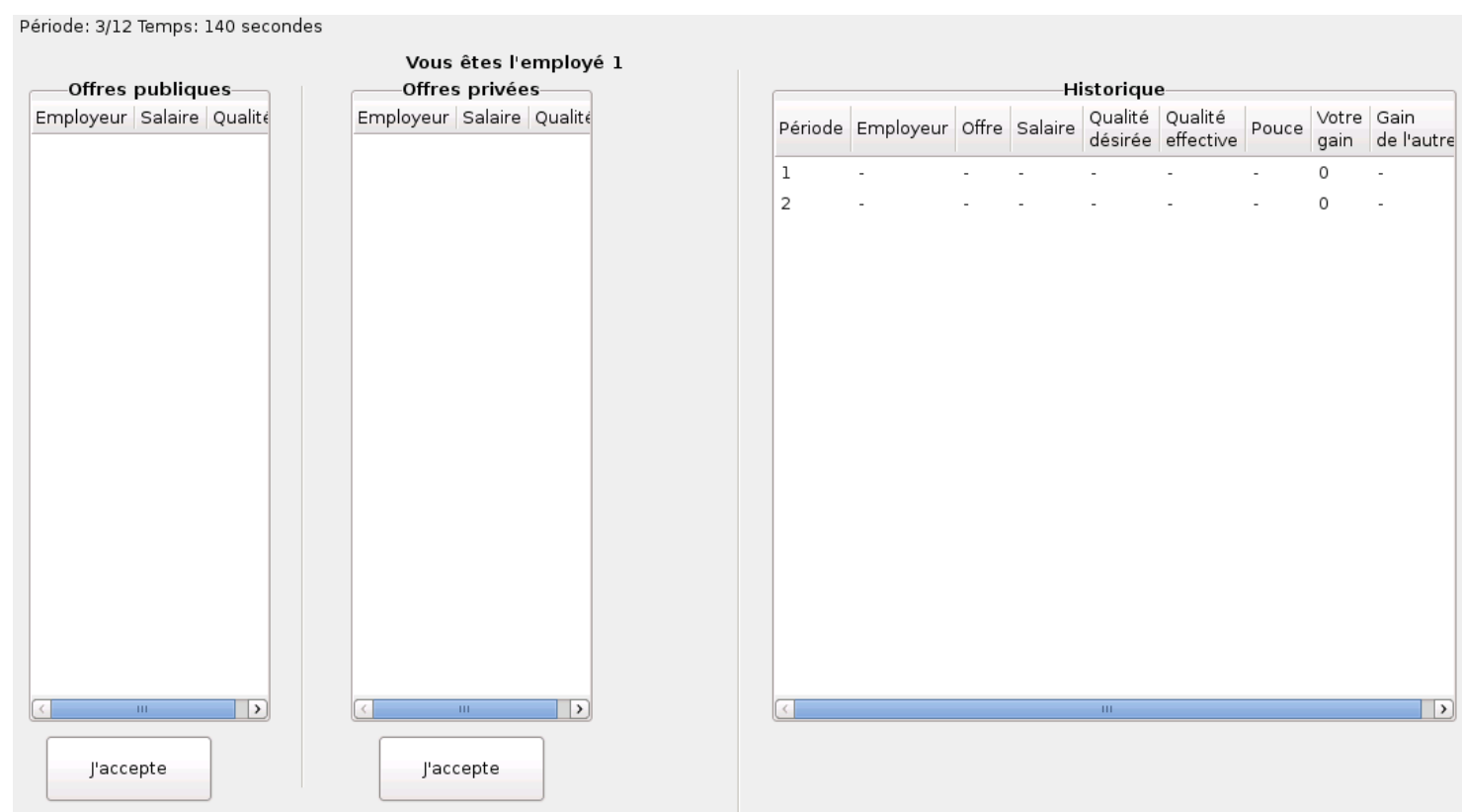

In the top left corner of the screen, you can see the number of the current period and the time remaining in this trading phase before the market closes.

How to submit an offer?

To submit an offer, the employer must indicate three elements on the left of the screen:

a) First, the employer specifies whether he wants to submit a private or a public offer.

\section{- Public offers}

The public offers are communicated to all participants in the market. All employees see all public offers on their screens. A public offer can be accepted by any employee. An employer can also see all the public offers submitted by all employers.

To submit a public offer, the employer has to click on the « public offer » field.

\section{- Private offers}

A private offer is submitted by an employer to one employee only. Only this employee is informed about the offer and only this employee can accept the offer. No other employer or employee will be informed about that offer.

To submit a private offer, the employer must click on the «private offer » field. After that he specifies the identification number of the employee he wants to submit an offer to. Each employee keeps his identification number throughout the whole experiment.

b) Once the employer has specified to whom he wants to submit an offer, he determines which wage he offers. This wage can take any value between 0 and 100 .

c) Finally, the employer determines the quality of work he desires. The quality of work can take any value between 1 and 10 . 
After the offer is completely specified, the employer clicks on the « validate » button. As long as the button is not clicked, the offer can be modified. After the employer has validated his offer, the offer is displayed in bold in the list of offers available on the market.

Each employer can submit as many public and private offers as he wishes during each period as long as there are employees available in the market. In the middle of the employer's screens the identification numbers of the remaining employees are kept visible.

All the public offers in the current trading phase are displayed on the left side of the employer's and employee's screens. It is possible to see which employer has submitted an offer, which wage he has offered, which quality of work he desires. All the employers have also an identification number that they keep throughout the whole experiment.

The private offers are displayed in the middle of the screen. It is possible to see on the employer's screen which private offers he has submitted to specific employees, with their identification numbers, which wage he has offered, and which quality of work he desires. One can see on the employee's screen which private offers he has been personally submitted in the current period, specifying the employers' identification numbers, the wage offered and the desired quality of work.

\section{How accept an offer?}

On the left of their screen, the employees can see the remaining public offers and the private offers they have received personally. To accept an offer, the employee must click on the row in which the offer is displayed to highlight it, and then click on the button «I accept » to validate his choice. Each offer can be accepted any time during the trading phase, after the first 20 seconds following the market opening.

In any given period, each employer and each employee can conclude at most one contract. Therefore, as soon as one of his offers has been accepted, all the other offers submitted by this employer are automatically cancelled. This employer is no longer allowed to submit other offers. The employer is informed on his offer that has been accepted and on the identification number of the employee who has accepted this offer.

After 3 minutes have elapsed, the trading phase is over even if all the employers and all the employees have not concluded a contract. If all the employees have concluded a contract before 3 minutes, the trading phase is shortened.

\section{Determination of work quality}

Following the trading phase, the employees who have concluded a contract choose which quality of work they supply to their respective employer. The quality chosen by the employee can differ from the quality desired by the employer.

The quality of work has to be between 1 and 10. Each quality level is associated to a cost. The higher the quality, the higher the cost to the employee, and the higher the employer's earnings (before deduction of wage), as indicated in the following Table:

\begin{tabular}{|l|c|c|c|c|c|c|c|c|c|c|}
\hline Quality of work & 1 & 2 & 3 & 4 & 5 & 6 & 7 & 8 & 9 & 10 \\
\hline Cost for the employee & 0 & 1 & 2 & 4 & 6 & 8 & 10 & 12 & 15 & 18 \\
\hline $\begin{array}{l}\text { Gain of the employer before } \\
\text { deduction of wage }\end{array}$ & 10 & 20 & 30 & 40 & 50 & 60 & 70 & 80 & 90 & 100 \\
\hline
\end{tabular}

The employer is informed on the quality of work actually supplied by his employee. No other employer or employee will be informed about that decision.

\section{Distribution of approval signs}


After being informed on the quality of work actually supplied by their employee, the employers have the possibility to express their approval to their employee by addressing him approval signs. These approval signs are represented by raised thumbs, as indicated in the following screenshot:

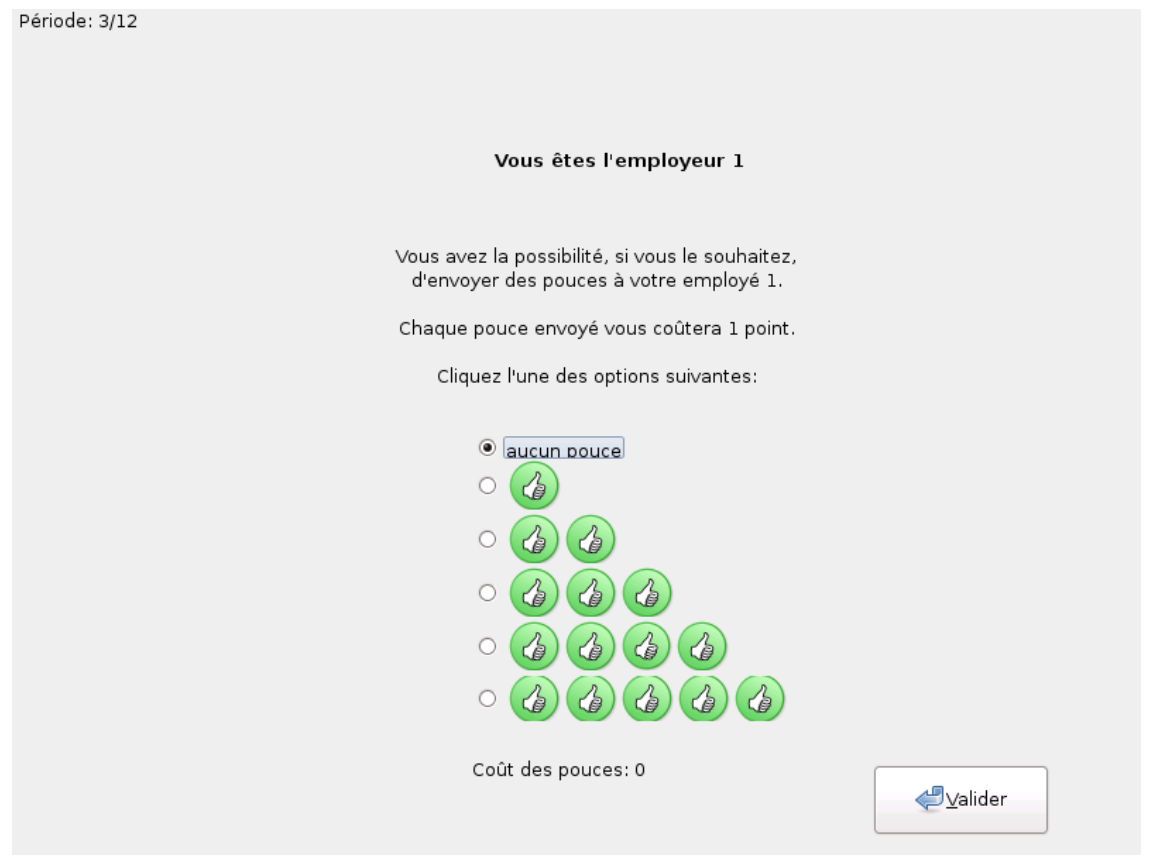

The employer can send between 0 and 5 thumbs to his employee. The employee is informed on the number of thumbs sent by his employer.

Receiving thumbs does not affect the employee's payoff. They only aim at expressing the employer's approval.

Each thumb addressed to an employee costs 1 point to the employer. The employer must enter a value between 0 and 5 and validate his decision.

\section{Calculation of payoffs}

\section{- The employer's payoff in a given period:}

- If the employer has not concluded a trade, the employer receives a payoff of 0 point.

- If the employer has concluded a trade, his payoff depends on the wage he has offered, the quality supplied by the employee and the number of approval signs sent to the employee. The employer's payoff is therefore determined as follows:

\section{Employer's payoff $=(10 *$ quality of work $)-$ wage - cost of thumbs}

\section{- The employee's payoff in a given period:}

- If the employee has not concluded a trade, the employee receives a payoff of 5 points.

- If the employee has concluded a trade, his payoff is equal to the wage he has received minus the cost of the quality of work supplied. The employee's payoff is therefore determined as follows: 
Employee's payoff $=$ wage - cost of the quality of work supplied

Note that it may happen that employers and employees can suffer losses in a given period. If any, the losses will be deducted from your initial endowment of 5 Euros or from the gains realized in the other periods.

Every one is informed of his own payoff and of the partner's payoff at the end of the current period.

\section{End of the period}

A summary table appears on your screen and the screen of the participant you have concluded a contract with, with the following information:

- the identification number of the employer or the employee

- the accepted wage

- the quality of work desired by the employer

- the quality of work supplied by the employee

- the number of thumbs sent by the employer to his employee

- your earnings for the current period

- the earnings of your partner for the current period, if any.

A new period starts automatically.

\section{Supplementary indicative question}

At the beginning of each period, each employee can see an indicative question on this screen. He must indicate if he is indifferent between all the employers or if he would prefer to receive a private offer from a specific employer. In this case, he has to indicate the identification number of this employer.

The answer to this question is purely indicative and it is communicated to none of the other participants, neither the employers, nor the employees. It has no influence on the offers received or on the payoffs.

To become familiar with the rules of this experiment, we invite you to read these instructions again and to answer the questions that will be displayed on your screen.

Next, you will perform 3 trials of the trading phase only (i.e., without choosing the quality of work to supply nor the approval signs). During these trials no money can be earned. For these trials you will be assigned a provisional identification number.

Following the 3 trials, the 12 periods that compose this experiment will start. The definitive identification numbers will be assigned for the rest of the experiment.

Please note that communication between participants is strictly prohibited during the experiment. Communication will lead to the exclusion from the experiment. In case you have any question, do not hesitate to raise your hand and we will answer your question in private. 
Appendix. Figure A. Mean number of symbolic rewards, by level of effort and by condition

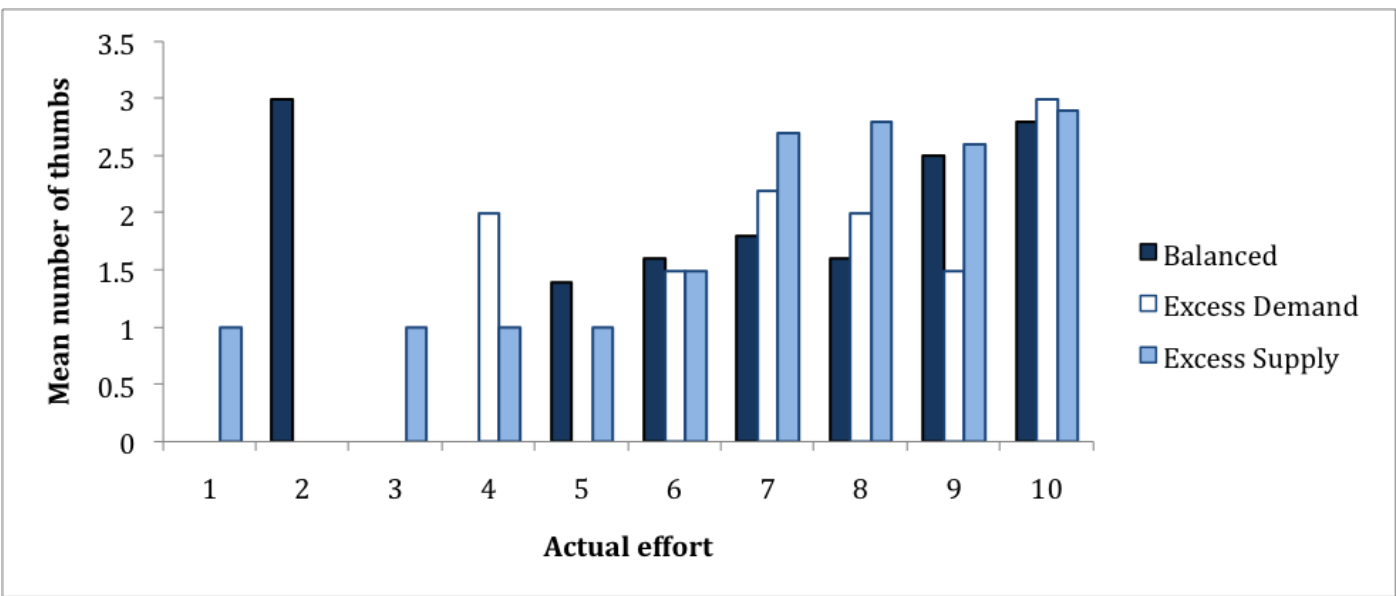

